ISSN $1978-3000$

\title{
Peningkatan Indeks Warna Kuning Telur dengan Pemberian Tepung Daun Kaliandra (Calliandra calothyrsus) dan Kepala Udang dalam Pakan Itik
}

\author{
Increasing Index by Using Calliandra Leaves Meals (Calliandra callothyrsus) \\ and Shrimp Head Meals in Duck Diets
}

Eli Sahara

Staf Pengajar Jurusan Peternakan Fakultas Pertanian Universitas Sriwijaya

\begin{abstract}
The yolk from intensive duck system mostly has pale color, so it is not interested to consumers. This condition is caused by the changing of raising pattern, from scavenging in to intensive duck system. In intensive duck system, the duck is fed by a mixture of concentrate and rice brand. The yellow pigment of yolk come from forage such as Sauropus androgynus Merr, Leucaena Leucocephala, Calliandra calothyrsus and Ipomoea aquatica and also from animal like shrimp waste (shrimp head). This experiment was used 30 duck (6 month old) and divided in to 3 treatments and 10 replicates, with 1 duck in each replication. The treatment were R1) $100 \%$ of basal diets (BD); R2) BD + 6\% of Calliandra leaves meals $(\mathrm{K})+3 \%$ of shrimp head meals $(\mathrm{SH}) ; 3) \mathrm{BD}+6 \%$ of $\mathrm{K}+6 \%$ of $\mathrm{SH}$. The result of the experiment showed that R1 treatment can increase yolk color index with the score, 11 and R2 got 10 . There was no significant effect of Calliandra leaves meals and shrimp head meals on consumption and ration efficiency, while for egg production showed the variability among individual duck in each treatment, only $40 \%$ in R0 produced egg, $60 \%$ in R1, and $80 \%$ in R2. The highest egg production in each treatment was found in R0 treatment $75 \%$, in R1 treatment was $66.7 \%$, and in R2 treatment was $50 \%$.
\end{abstract}

Key word : Duck, calliandra leaves, shrimp head, egg yolk colour index

\begin{abstract}
ABSTRAK
Telur itik yang berasal dari pemeliharaan intensif banyak yang pucat, sehingga kurang disukai oleh konsumen. Hal ini disebabkan oleh perobahan pola pemeliharaan dari sistem gembala ke sistem terkurung karena pada sistem terkurung pakan yang diberikan adalah campuran konsentrat, menir dan dedak. Sumber pigmen penguning warna kuning telur dapat diperoleh dari hijauan seperti daun katuk, lamtoro, kaliandra dan kangkung serta dari hewani seperti limbah udang. Pada penelitian ini digunakan 30 ekor itik umur \pm 6 bulan yang dibagi dalam 3 perlakuan dan 10 ulangan dengan masing-masing ulangan terdiri dari 1 ekor itik. Perlakuan 1 adalah RB 100\%, perlakuan 2 adalah RB + K 6\% + CU 3\% dan perlakuan 3 adalah RB + K 6\% + CU 6\%. Hasil penelitian menunjukkan bahwa perlakuan R1 (ransum basal $+6 \%$ kaliandra $+3 \%$ kepala udang) dapat meningkatkan indeks warna kuning telur dengan skor 11, dan perlakuan R2 (ransum basal $+6 \%$ kaliandra $+6 \%$ kepala udang) dengan skor 10. Tidak terdapat pengaruh perlakuan kaliandra dan kepala udang terhadap konsumsi ransum dan efisiensi ransum, sedangkan untuk produksi telur terdapat variasi antar individu itik untuk masing-masing perlakuan yaitu itik pada perlakuan R0 hanya $40 \%$ yang bertelur, itik pada perlakuan R1 $60 \%$ yang bertelur dan itik pada perlakuan R2 80\% yang bertelur. Kalau dilihat untuk masing-masing perlakuan, itik yang berproduksi telur tinggi untuk perlakuan R0 adalah 75\%, R1 yang berproduksi tinggi adalah $66.7 \%$ dan R2 yang berproduksi tinggi hanya $50 \%$.
\end{abstract}

Kata Kunci : Itik, daun kaliandra, kepala udang, indeks warna kuning telur

\section{PENDAHULUAN}

Warna kuning telur itik yang pucat tidak disukai oleh konsumen, terutama untuk telur itik yang diasin. Hal tersebut sangat mempengaruhi nilai jual dari pada telur itik. Permasalahan yang sering 
muncul adalah konsumen seringkali memprediksikan warna kuning telur yang cerah ada hubungannya dengan khasiat dan kualitas dari telur sehingga warna kuning telur itik yang pucat akan menurunkan nilai jual dari telur tersebut.

Perubahan cara pemeliharaan itik dari sistem ekstensif menjadi intensif menyebabkan warna kuning telur itik pucat. Hal ini disebabkan karena pada pemeliharaan intensif digunakan pakan campuran konsentrat, dedak, menir atau jagung. Bila jagung yang digunakan berwarna putih maka warna kuning telurnya akan pucat. Pada pemeliharaan ekstensif, itik mendapat kesempatan untuk memakan sumber-sumber pigmen penguning telur seperti tanaman hijauan di sawah atau ladang penggembalaan. Untuk menghasilkan warna kuning telur yang pekat dapat ditambahkan pigmen pewarna kuning telur. Pigmen pewarna kuning telur adalah karotenoid. Pigmen tersebut dapat dalam bentuk siap pakai (pigmen sintetis), tanaman hijauan atau bahan alami lain seperti cangkang udang. Bila digunakan pigmen siap pakai akan meningkatkan biaya pakan karena merupakan bahan impor dan harganya mahal.

Hewan tidak dapat membuat sendiri karotenoid dalam tubuhnya, karotenoid dapat diperoleh dengan memakan bahan makanan nabati yang banyak mengandung karotenoid. Pigmen karotenoid tersebut sebagian besar terdiri dari lutein dan zeaxanthin yang termasuk dalam istilah xanthophyll.

Di Indonesia penelitian menggunakan sumber pigmen alami seperti daun kaliandra, kangkung, daun katuk dan daun lamtoro sudah terbukti dapat meningkatkan indeks warna kuning telur, namun belum diketahui dosis yang dapat menghasilkan warna dengan indeks yang tinggi yaitu antara 10-12. Berdasarkan uraian di atas maka penelitian dilakukan dengan penggunaan sumber karotenoid dari jenis tanaman dan hewani yaitu tepung daun kaliandra dan tepung kepala udang dalam pakan.

Penelitian ini bertujuan meningkatkan indeks warna kuning telur dengan pemberian sumber pigmen alami yaitu kaliandra dan kepala udang serta pengaruhnya terhadap keamanan organ dalam.

\section{MATERI DAN METODE}

Dalam penelitian ini digunakan 30 ekor itik alabio betina dewasa yang terbagi ke dalam 3 perlakuan, 10 ulangan dan masing-masing ulangan terdiri dari 1 ekor itik Itik ditempatkan pada kandang baterai (individual cage) secara acak. Setiap kandang dilengkapi tempat pakan dan tempat air minum yang terbuat dari paralon. Air minum diberikan secara adlibitum. Ransum perlakuan yang digunakan adalah satu tingkat penggunaan kombinasi tepung daun kaliandra dan tepung kepala udang yang dicampurkan ke dalam ransum basal yaitu $\mathrm{RO}$ (ransum basal 100\% sebagai kontrol), R1 (kaliandra $6 \%+$ kepala udang 3\%) dan R2 (kaliandra $6 \%+$ kepala udang 6\%). Peubah yang diamati adalah konsumsi ransum, produktivitas telur, efisiensi penggunaan ransum, indeks warna kuning telur dan retinol serum itik. data dianalisis secara statistik dan untuk produksi telur ditampilkan secara deskriptif.

\section{HASIL DAN PEMBAHASAN}

\section{Konsumsi Ransum}

Rataan konsumsi pakan per perlakuan selama penelitian, untuk itik yang diberi pakan perlakuan R0, R1 dan R2 disajikan pada Tabel 1. 
Tabel 1 Konsumsi ransum itik selama tiga minggu (gram)

\begin{tabular}{cc}
\hline Perlakuan & Konsumsi Ransum (gram) \\
\hline R0 & $2795.53 \pm 229.07$ \\
R1 & $2599.40 \pm 461.51$ \\
R2 & $2835.80 \pm 459.08$ \\
\hline
\end{tabular}

Hasil analisis ragam menunjukkan bahwa konsumsi ransum untuk masingmasing perlakuan hampir sama atau tidak menunjukkan perbedaan yang nyata. Hal ini berarti tidak ada pengaruh perlakuan (pemberian kaliandra dan kepala udang) dalam pakan terhadap konsumsi ransum sehingga tidak mengurangi palatabilitas dari pakan.

\section{Produksi Telur}

Produksi telur masing-masing itik selama 3 minggu untuk 30 ekor itik disajikan dalam Gambar 1. Dari Gambar 1 terlihat bahwa produksi telur masingmasing perlakuan cukup beragam dimana itik pada perlakuan $\mathrm{R} 0$ hanya $40 \%$ yang bertelur, itik pada perlakuan R1 60\% yang bertelur dan itik pada perlakuan R2 80\% yang bertelur. Ini menunjukkan bahwa dari masing-masing perlakuan untuk setiap ulangan terdapat variasi kemampuan berproduksi telur antar individu itik cukup besar, dimana perlakuan R0 yang berproduksi tinggi 75\%, R1 yang berproduksi tinggi $66.7 \%$ dan R2 yang berproduksi tinggi hanya 50\%. Dari keseluruhan jumlah itik yang bertelur, terdapat itik yang berproduksi tinggi adalah $61 \%$, sedangkan $39 \%$ lagi tergolong itik berproduksi rendah. Penyebab dari rendahnya produksi yang didapat dari penelitian ini perlu dicari jawabannya. Ada 3 faktor penting yang berperan dalam kemampuan itik untuk menghasilkan telur yaitu 1) faktor kebakaan 2) faktor lingkungan dan 3) faktor pakan. Kemungkinan ini erat hubungannya seperti yang dikatakan Hardjosworo et al. (2001) bahwa keragaman dalam produktivitas itik lokal sangat tinggi karena itik-itik yang memiliki kemampuan berproduksi tinggi dengan yang rendah di tangan peternak mendapat kesempatan yang sama untuk berkembang biak.

\section{Efisiensi Penggunaan Ransum}

Rataan efisiensi ransum per perlakuan selama penelitian, untuk itik yang diberi ransum R0, R1 dan R2 disajikan pada Tabel 2.

Tabel 2 Efisiensi ransum terhadap produksi telur total selama penelitian

\begin{tabular}{cc}
\hline Perlakuan & Efisiensi Ransum \\
\hline R0 & $0.30 \pm 0.18$ \\
R1 & $0.25 \pm 0.15$ \\
R2 & $0.23 \pm 0.17$ \\
\hline
\end{tabular}


Berpatokan ke produksi telur yang dihasilkan oleh masing-masing itik yang beragam dan konsumsi ransum selama 3 minggu, maka efisiensi ransum untuk masing-masing itik juga berbeda. Dari analisis ragam terlihat ada kecenderungan itik pada perlakuan R0 mempunyai efisiensi yang lebih baik dari itik pada perlakuan R1 dan R2. Angka efisiensi ransum yang semakin besar menunjukkan efisiensi ransum yang semakin baik karena semakin baik kemampuan itik menggunakan 1 gram ransum untuk menghasilkan telur (gram). Pada perlakuan R0 terdapat itik yang berproduksi tinggi 75 $\%$, sedangkan itik perlakuan R1 dan R2

Produksi Telur Itik se lama 3 Minggu

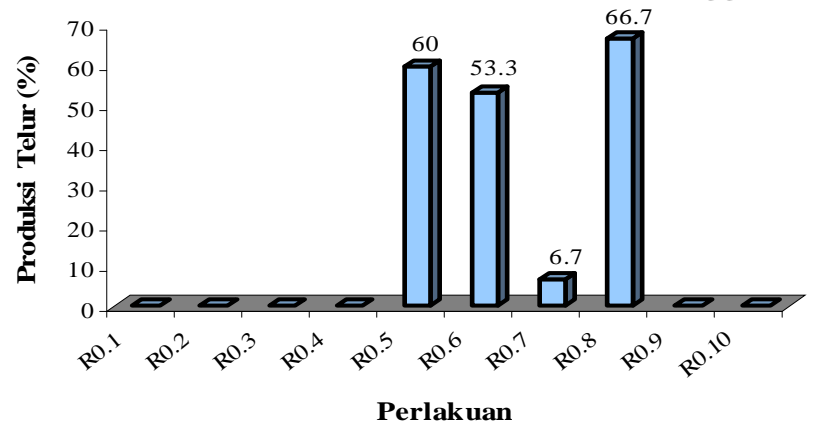

(a)

Persentase Produksi Telur (\%)

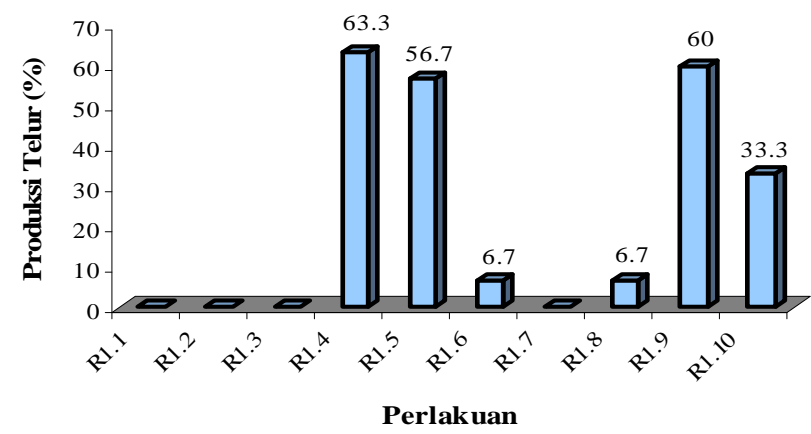

口 Persentase Produksi Telur (\%)

(b)

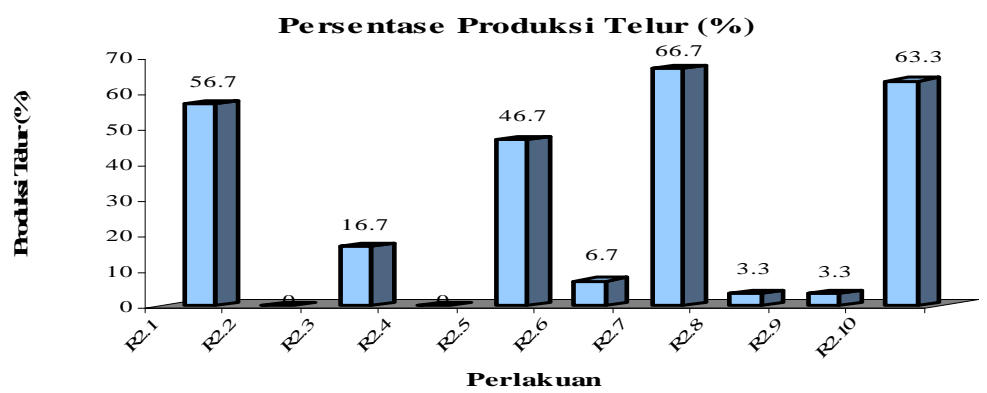

D Persentase Produksi Telur (\%)

(c)

Gambar 1 Pengaruh pemberian daun kaliandra dan kepala udang terhadap produksi telur itik selama 3 minggu dari 30 ekor itik; a) untuk perlakuan R0 (itik no 1 sampai 10), b) perlakuan R1 (itik no 1 sampai 10), dan c) perlakuan R2 (itik nomor 1 sampai 10). 
produksinya lebih rendah. Efisiensi ransum itik pada perlakuan R2 paling rendah karena besarnya konsumsi ransum tidak diikuti oleh tingginya produksi telur (50\%). Rataan efisiensi ransum penelitian adalah $0.23-0.30$. Artinya satu gram ransum yang dikonsumsi oleh itik akan menghasilkan berat telur antara $0.23-0.30$ gram.

\section{Indeks Warna Kuning Telur}

Indeks warna kuning telur dari perlakuan kombinasi kaliandra dan kepala udang dapat dilihat pada Gambar 2. Dari Gambar 2 terlihat perlakuan R1 (6\% kaliandra $+3 \%$ kepala udang) memberikan indeks warna kuning telur paling tinggi dengan skor 11 .

Peningkatan indeks warna kuning telur mulai stabil dari hari ke 7 sampai hari ke 14. Pada perlakuan R2 (6\% kaliandra + $6 \%$ kepala udang) memberikan indeks warna kuning telur dengan skor 10. Perlakuan R0 memberikan indeks warna kuning telur dengan skor 6 .

$$
\text { Meningkatnya indeks warna }
$$
kuning telur dengan pemberian kaliandra dan kepala udang jelas disebabkan oleh pigmen karotenoid yang terkandung dalam kaliandra dan kepala udang. Pemberian kombinasi kaliandra 6\% dengan kepala udang 3\% (R1) memberikan indeks warna kuning telur paling tinggi (skor 11) dibanding R2 (kaliandra 6\% dengan kepala udang 6\% ) yaitu 10. Pakan R2 mengandung kepala udang lebih tinggi dari R1, kemungkinan kelebihan khitin yang terdapat dalam pakan R2 tidak mudah dicerna. Hal ini dapat menimbulkan zat-zat gizi termasuk vitamin dan carotene pemberi warna pada kuning telur tidak sempurna terdeposit ke kuning telur. Tetapi pada perlakuan R1 merupakan kombinasi kaliandra dan kepala udang yang tepat. Carotene yang terkandung dalam pakan perlakuan R1 lebih cepat diserap dan dideposisikan ke kuning telur. Suharja (2010) menyatakan bahwa proses metabolisme karotenoid berbeda diantara hewan termasuk perioritas jenis-jenis karotenoid yang diserap dalam sistim pencernaan. Kecuali itu deposit pigmen di dalam tubuh ternak juga sangat dipengaruhi oleh kandungan lemak karena karotenoid larut dalam lemak. Sistim pencernaan lemak dalam tubuh dibantu oleh adanya garam empedu yang dihasilkan oleh hati. Garam-garam empedu mempunyai sejumlah peranan yang penting. Garam-garam empedu bergabung dengan lipid untuk membentuk micelles kompleks yang larut dalam air supaya lipid dapat lebih mudah diserap (Ganong 1995). Carotene akan lebih efisien

Indeks Warna Kuning Telur Penelitian Lanjutan

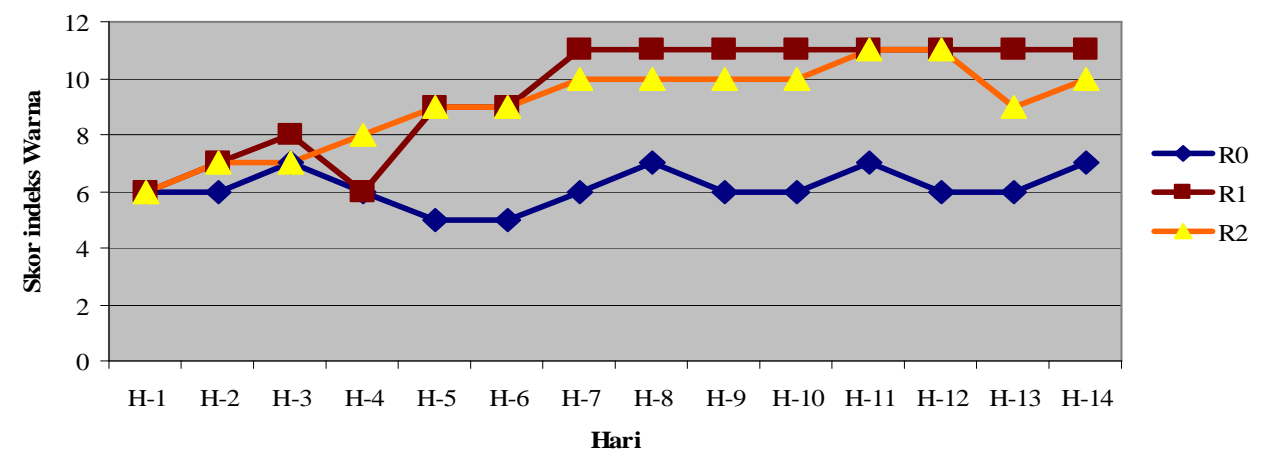

Gambar 2 Pola indeks warna kuning telur dengan pemberian pakan R0 (ransum basal), R1 (6\% kaliandra $+3 \%$ kepala udang), R2 (6\% kaliandra $+6 \%$ kepala udang). 


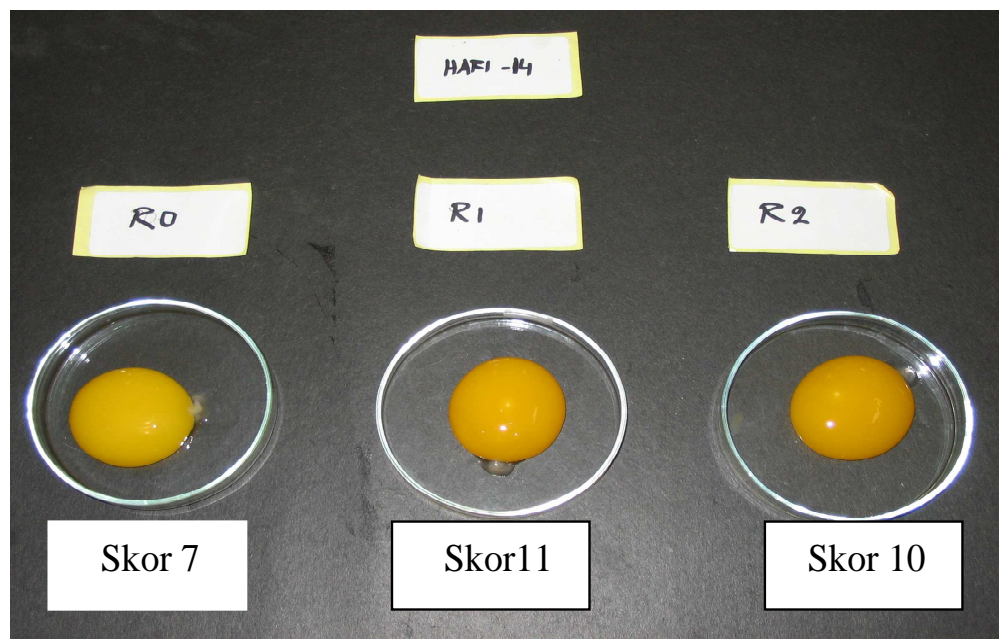

Gambar 6 Indeks warna kuning telur dengan pemberian pakan R0 (ransum basal), R1 (6\% kaliandra + 3\% kepala udang),R2 (6\% kaliandra $+6 \%$ kepala udang).

dipergunakan oleh tubuh dalam jumlah sedikit di dalam makanan (Tim Peneliti PAU Pangan dan Gizi-IPB 1993). Oleh sebab itu penyerapan $\beta$-carotene bervariasi.

\section{Retinol Serum Itik}

Kadar retinol serum itik untuk masing-masing perlakuan R0, R1 dan R2 dapat dilihat pada Tabel 3. Darah diambil pagi hari, dari 2 (dua) ekor itik untuk masing-masing perlakuan, dimana untuk masing-masing perlakuan diambil itik yang bertelur diatas 30\% dan dibawah $20 \%$ secara acak.

Tabel 3 Pengaruh pemberian perlakuan kombinasi kaliandra dan kepala udang dalam pakan terhadap kadar retinol serum itik

\begin{tabular}{lc}
\hline \multicolumn{1}{c}{ Perlakuan } & Kadar retinol serum $(\mu \mathrm{g} / \mathrm{dl})$ \\
\hline R0 & 57.30 \\
R1 & 34.95 \\
R2 & 43.20 \\
\hline
\end{tabular}

Pada Tabel 3 terlihat retinol serum R1 dan R2 lebih rendah dibanding retinol serum itik pada perlakuan R0. Flora, Bagnasco dan Vainio (1999) menyatakan bahwa konsentrasi karotenoid dalam darah ditentukan oleh level karotenoid dalam ransum. Hal ini terlihat pada perlakuan R1 dan R2 pigmen carotene nya lebih cepat terdeposit ke dalam kuning telur karena kadar lemak dan protein ransum yang berfungsi sebagai carrier pada perlakuan R1 $(3.10 \%$ lemak dan $22.99 \%$ protein ) dan R2 (3.33\% lemak dan $24.16 \%$ protein) lebih tinggi dari R0 (2.79\% lemak dan $20.61 \%$ protein). Dengan demikian, retinol yang tersedia dalam darah pada perlakuan R1 dan R2 sudah lebih dulu disebarkan ke seluruh folikel yang ada. Pernyataan ini diperkuat oleh Piliang dan Al Haj (2000) bahwa asam empedu mempunyai sifat hidrotropik yaitu zat yang mampu mengikatkan dirinya dengan zat-zat yang tidak larut di dalam air sehingga retinol (vitamin A dalam darah) menjadi larut di dalam air dan mudah diserap oleh mukosa usus disebabkan efek asam empedu pada zat-zat tersebut seperti efek asam empedu terhadap asam lemak Hal ini diperkuat oleh indeks warna kuning telur pada perlakuan R1 dan R2 adalah rata-rata 10 yang lebih tinggi dari R0 rata-rata 5.

\section{SIMPULAN}

Pemberian tepung daun kaliandra dan tepung kepala udang dalam ransum 
tidak berpengaruh terhadap konsumsi ransum dan efisiensi ransum, tapi dapat meningkatkan indeks warna kuning telur paling baik yaitu dengan skor 11 .

\section{DAFTAR PUSTAKA}

Flora SD, Bagnasco M, Vainio H. 1999. Modulation of Genotoxic and Related Effects by Carotenoids and Vitamin A in Experimental Models: Mechanistic Issues. Review Mutagenesis. 14: 153-172.

Ganong WF. 1995. Fisiologi Kedokteran. Edisi 14. Jakarta: EGG Penerbit Buku Kedokteran.

Hardjosworo PS et al. 2001. Perkembangan Teknologi Peternakan Unggas Air di Indonesia. Di Dalam : Pengembangan Agribisnis Unggas Air sebagai Peluang Usaha Baru. Prosiding Lokakarya Unggas Air; Bogor: Fakultas Peternakan Institut Pertanian Bogor, Balai Penelitian Ternak Pusat Penelitian dan Pengembangan Peternakan. Hlm 22-41.

Piliang WG dan Al Haj S. 2006. Fisiologi Nutrisi Vol 1. IPB Press

Suharja. 2010. Mengendalikan Pigmentasi Kuning Lewat Pakan. Feed TeknoIndustri Pakan Ternak Indonesia

Tim Peneliti PAU Pangan dan Gizi-IPB. 1993. Studi Dampak Intervensi Sayuran Sumber Vitamin A Terhadap Status Vitamin A dan Perilaku Konsumsi Sayuran Sumber Vitamin A. Laporan Penelitian. Pusat Antar Universitas Pangan dan Gizi IPB. 